\title{
The Great Takeover Debate: A Meditation on Bridging the Conceptual Divide
}

\author{
William T. Allen $\dagger$ \\ Jack B. Jacobs $\dagger \uparrow$ \\ Leo E. Strine, Jr. $\uparrow \dagger \uparrow$
}

The past two decades have witnessed a vigorous continuation of the long-standing debate about the proper role of the corporation in our society. Recently, that debate has centered on the question of who-the directors or the stockholders-should have the ultimate power to decide whether the corporation should be sold to a bidder that offers to buy all the corporation's shares at a substantial premium above the current stock market price. The contestants in this debate have been unable to reach any middle ground. That impasse is due in part to ideological differences between the two schools, but it is also due in part to a general satisfaction with the results achieved by the current state of Delaware corporate fiduciary law, which incorporates elements of, and balances, both positions. To relocate the debate to a different and perhaps more fruitful path, the authors suggest an approach that might provide a middle ground between the these two schools: corporate election reform. This Article raises, for discussion purposes only, the issue of whether it is possible to reform the director election process to increase director accountability to the stockholders while at the same time creating a cadre of directors having considerable flexibility to respond to takeover offers in a manner appropriately sensitive to shareholder interests. To stimulate more productive discussion about the nature of the corporation and the role of corporate law, the authors propose-without embracing-a reform that they suggest might have this effect.

\section{INTRODUCTION}

We begin a new century with a debate that is old but persistent. It concerns a basic issue: what is the purpose of the corporation? In rough terms, the question is whether corporation law exists solely in order to facilitate shareholder economic welfare or whether the "republican" form of corporate governance represents a partial commitment by the law to values in addition to implementing shareholder will. On this question, we think that the corporation law of Delaware remains ambivalent. That fact is significant, given Delaware's leading

$\dagger$ Jack Nusbaum Professor of Law \& Business, New York University; former chancellor, Delaware Court of Chancery, 1985-97.

t† Vice Chancellor, Delaware Court of Chancery.

t† $\dagger$ Vice Chancellor, Delaware Court of Chancery.

The authors gratefully acknowledge the assistance of Andrew H. Lippstone, Esq., and Karlis P. Johnson in the preparation of this Article. We also appreciate the useful thoughts provided by Ehud Kamar, Marcel Kahan, Lisa Bernstein, Lucian Bebchuk, Mark Roe, Thomas Cole, Isaac Corre, and Paul Rowe. 
role in the market for incorporations and the apparent influence of Delaware corporation law upon judicial decisions and corporate statutes in several other states. It is, therefore, not surprising that the ambivalence of Delaware corporation law on this basic issue remains a primary focus of debate by legal scholars, economists, and corporate practitioners.

In commenting on that debate in this Article we do not pretend to emulate the depth of scholarship of law professors or the financial insights of economists or, for that matter, the practical experience of those who negotiate and craft mergers and acquisitions on a daily basis. Although we do not here write in a judicial capacity, ${ }^{1}$ we do bring to bear the unique perspective of judges who have grappled with that ambivalence on a daily basis for an extended time.

Because the statutory corporation law is broadly enabling in character and the primary restraint placed on corporate directors is vaguely stated in the nomenclature of fiduciary duty, the policy of the corporation law is inevitably shaped at least in the first instance through judicial decisions. The statutory foundation for Delaware's corporation law, the Delaware General Corporation Law ("DGCL"), broadly empowers corporations to accomplish virtually any lawful act, subject only to the requirement that the acts be accomplished in the manner provided in the statute and that they be approved by directors acting in conformity with their fiduciary obligations. Although there are some counterexamples, ${ }^{2}$ amendments to the DGCL have rarely been the method used to confront the major developments occurring in the mergers and aquisitions marketplace during the last thirty years. For the most part, the Delaware General Assembly has left it largely to the courts-specifically, the Court of Chancery and the Delaware Supreme Court-to shape legal rules that are responsive to those developments, using the case-by-case model of adjudication. In that legislative vacuum, it is unavoidable that the process for developing those legal rules will involve policy choices.

Thus, important policy-laden questions, such as the validity of a shareholder rights plan or "poison pill," the ability of directors to de-

1 Since our views are expressed only in our capacity as lay commentators, nothing in this Article should be regarded as an opinion or prediction of how we would decide particular issues presented to us in our official capacity.

2 See, for example, Delaware's relatively modest antitakeover statute, 8 Del Code Ann $\$ 203$ (2001), which is far less extreme than those of most other states. See also Lucian Arye Bebchuk, Alma Cohen, and Allen Ferrell, Does the Evidence Favor State Competition in Corporate Law?, 90 Cal L Rev (forthcoming 2002) (comparing the strength of state antitakeover statutes and showing that Delaware's antitakeover statute is relatively weak).

3 See Moran v Household International, Inc, 500 A2d 1346, 1354 (Del 1985) (upholding the adoption of a poison pill). See also Quickturn Design Systems, Inc v Mentor Graphics Corp, 721 A2d 1281, 1291-92 (Del 1998) (invalidating a "delayed redemption," or "slow-hand," poison 
ploy defensive measures in response to takeover bids, ${ }^{4}$ and the duties imposed on directors when selling the corporation, ${ }^{5}$ have been addressed primarily by the Delaware courts rather than by amendments to the corporate statute. Judges charged with deciding these difficult questions, while privileged to be entrusted with such exciting and interesting work, cannot help but be humbled by their awareness of the social and economic importance of those issues, and of the fact that the adjudicative tools available to resolve those issues are blunt.

The case-by-case mode of decisionmaking forces judges to answer only the questions posed to them by the parties, within the limited context of a record that the parties themselves create. Accordingly, the prism through which judges view the world is, for institutional reasons, artificially narrow, and can only be broadened (and even then only imperfectly) by consulting the relevant literature. Unlike administrative agencies, a court cannot submit a draft of a judicial opinion for initial scrutiny, commence a public hearing and comment process to obtain valuable feedback and empirical information from a larger public, and then use that feedback to refine its draft into a final product that may reflect changes in initial direction.

These limitations are compounded by the time pressure under which judges are forced to operate when deciding corporate disputes (often arising in an expedited injunctive context)-pressure that diminishes the opportunity to reflect adequately upon the full ramifications of the policy choices the judges are being asked to make. For this reason, Delaware courts have hewed largely to the traditional approach of writing narrowly and only for the case at hand, and have generally avoided sweeping policy pronouncements. ${ }^{6}$ This tentative,

pill); Carmody v Toll Brothers, Inc, 723 A2d 1180, 1190-94 (Del Ch 1998) (invalidating a deadhand poison pill).

4 See Unitrin, Inc v American General Corp, 651 A2d 1361, 1390 (Del 1995) (holding that the adoption of a poison pill and a limited repurchase program, although making a takeover more difficult, may nonetheless be reasonable defensive measures); Unocal v Mesa Petroleum Co, 493 A2d 946, 955-56 (Del 1985) (approving as reasonable a board decision to offer a selective exchange of shares in response to the threats posed by an inadequate and coercive merger offer).

5 See Paramount Communications, Inc v QVC Network, Inc, 637 A2d 34, 48 (Del 1994) (holding that the duty to maximize shareholder value exists when the corporation undertakes a transaction that will cause a change in corporate control); Revlon, Inc v MacAndrews \& Forbes Holdings, Inc, 506 A2d 173, 182 (Del 1986) (holding that at the point at which the breakup and sale of a company becomes inevitable, the duty of the board is to maximize the company's value to the shareholders' benefit).

6 See, for example, Marcel Kahan and Ehud Kamar, Price Discrimination in the Market for Corporate Law, 86 Cornell L Rev 1205, 1239 (2001) (making the point that Delaware corporate decisions are crafted in this manner); Ehud Kamar, Shareholder Litigation under Indeterminate Corporate Law, 66 U Chi L Rev 887, 891 (1999) ("Indeed, courts often emphasize their incompleteness, leaving the legal community wondering what additional criteria may prove relevant in the future."). 
case-specific approach lends itself to low-cost innovations and midcourse corrections, because a carefully-cabined policy experiment can be abandoned or tempered with greater ease and grace than one that is broadly gauged and expansive. Given the informational, ethical, and time constraints that hamper the adjudicative process as a method for policymaking, this approach also reflects appropriate modesty.

Policy development by adjudication is more comfortable when the case at hand requires the judge to flesh out the details necessary to create a workable framework to further a policy goal that is already clearly spelled out by the DGCL - for example, the need to police self-dealing. ' In cases in which there is no underlying policy principle addressed by the DGCL and none is firmly established in the common law of fiduciary duty, however, the judicial task unavoidably (and awkwardly) acquires legislative characteristics. That is the case even though judges do not like to regard themselves openly as making law, that is, as forthrightly choosing to select a particular public policy from among a range of plausible choices, and then articulating that discretionary choice as a principle of positive law. Even Justice Benjamin Cardozo, who wrote so candidly about the lawmaking role of judges, downplayed and enshrouded that role in his own judicial decisions. ${ }^{8}$

Reticence to express an adjudicative decision as a policy choice comes naturally with the acceptance of the judicial role. A policy choice is a debatable proposition that exposes the court to the same kinds of criticism directed against policymakers within the "political" branches of government. Most judges worry about the legitimacy of their policymaking authority. Unlike members of the political branches, they cannot fall back on a popular mandate, nor can they freely engage the critics of their decisions. It is therefore institutionally safer and more conforming with tradition to write judicial opinions in a way that obscures policy choices, often by suggesting that those choices are simply the only logical next step in a trail blazed by statutory law and earlier judicial decisions. Judges fervently endorse the wisdom in Yogi Berra's malapropism, "when you get to a fork in the road, take it," but they add some words of wisdom of their own, namely, "take it fast and hope everyone else along for the ride doesn't notice there was a choice about which way to go."

Judicial reluctance to surface the difficult policy choices that often underlie corporate law adjudication often manifests itself in elision, that is, the tendency for courts to omit or blur the distinctions between contradictory ideas. When possible, a court will often avoid re-

\footnotetext{
7 See 8 Del Code Ann $\$ 144$ (2001).

8 See generally Dan Simon, The Double-Consciousness of Judging: The Problematic Legacy of Cardozo, 79 Or L Rev 1033 (2000).
} 
solving an open issue of public policy arguably implicated by the case at hand. It may, for example, leave the resolution of such an issue to another day when matters have become clearer or (more wishfully) when the legislature has supplied more concrete guidance. Sometimes courts also strive to reconcile competing policy principles by locating a rhetorical common ground on which a case-specific decision can safely rest.

During the past three decades, all these characteristics of judicial policymaking have manifested themselves in decisions of the Delaware courts addressing important matters of corporate law policy, and for good reason. In the background of virtually every major Delaware M\&A decision lurks a fundamental policy question that the Delaware General Assembly has not addressed. As one of us noted almost a decade ago, Delaware law has yet to make a definitive choice between the two basic models of the corporation - the "property" and the "entity" models that have dominated American corporation law scholarship and jurisprudence for the last one hundred years.

Competing political and philosophic views of the nature and purpose of the corporation may yield rather different answers to the most basic and arguably most persistent controversy in corporation law: What is the core purpose of the corporation? Is it to achieve the best result for the current group of stockholders? That position is associated with what we call the "property model" of the corporation. Or is it to maximize the value that the corporation generates as an entity in the long term, regardless of whether that is in the best interests of the current stockholders? That view is associated with what has been called the "entity model" of the corporation.

The focal point of the ongoing debate between the adherents of these two schools for most of the last quarter-century has been fixedalmost obsessively-on the area of takeover proposals, and specifically, on the question of who has primacy to decide whether to accept an "all-shares" tender offer-stockholders or directors?" The property

9 See William T. Allen, Our Schizophrenic Conception of the Business Corporation, 14 Cardozo L Rev 261, 264-66 (1992).

10 The provocative exchange between Lucian Bebchuk and Martin Lipton in this Symposium reflects the ongoing vibrancy of that debate. See Lucian Arye Bebchuk, The Case Against Board Veto in Corporate Takeovers, 69 U Chi L Rev 973 (2002) (arguing that boards should not be permitted to block tender offers beyond the period necessary for preparing alternatives for shareholder choice); Martin Lipton, Pills, Polls, and Professors Redux, 69 U Chi L Rev 1037 (2002) (arguing that there are significant costs to corporations in being managed as if they were for sale, and justifying the poison pill as a device to reduce these costs). So does the current debate between Martin Lipton and Ronald Gilson. See Ronald J. Gilson, Unocal Fifteen Years Later (and What We Can Do about It), 26 Del J Corp L 492, 508-09 (2001) (advocating the use of shareholder bylaws to redeem poison pills, returning to shareholders some control over the result of tender offers); Martin Lipton and Paul K. Rowe, Pills, Polls, and Professors: A Reply to Professor Gilson, 27 Del J Corp L (forthcoming 2002) (arguing that a judicial declaration of the 
modelists, who are viewed as advocates of shareholder choice, contend that the stockholders themselves must be permitted to accept or reject a tender offer once the directors have had the opportunity to negotiate for a higher price, to seek better deals, and to present a noncoercive alternative. By contrast, the entity modelists regard director decisionmaking as primary. When informed directors have made a goodfaith decision that an all-shares tender offer is not in the long-run best interests of the corporation, this school advocates that directors must be permitted to "just say no" on the stockholders' behalf.

In this Article, we comment on the current state of this debate, not as judges qua judges but from the perspective of individuals who have been called upon to decide corporate law cases in which those questions are sometimes explicit and often implicit. We take no position on the merits of these two basic competing schools of thought. We do, however, raise some difficulties with each model that will likely concern judges being asked to lean towards one school or the other. Specifically, we identify normative, empirical, and practical problems arising out of each school's unique perspective-problems that limit the probability that either school of thought will be adopted in full by courts, especially in the absence of a clear legislative mandate in favor of either position.

More provocatively, we also take the liberty of pointing out that the major participants in the debate seem to be talking past each other. Because their basic conceptions are so fundamentally at odds, the contestants sometimes advance what seem to be other-worldly suggestions for reform that, although they have intellectual integrity, have no realistic chance for implementation. Finally, without in any way adopting the idea as reflecting our personal normative beliefs (individually or collectively) as to what would be good public policy, we offer for debate a reform that could potentially bridge the gap separating the adherents of the property and the entity models.

Our suggested concept is that the corporate election system be reformed in a fundamental way that would require each side in the debate to sacrifice some theoretical purity in exchange for something of practical value. Instead of annual corporate elections, corporations would hold director elections only once every three years. But, rather than allowing management to dominate the proxy machinery and company election resources to the exclusion of outsiders, equal access to the proxy machinery would be afforded to nominees who are proposed for election to the board by stockholders having at least 5 percent of the company's voting power. In this way, the corporate election 
process will become meaningful at each election, and not just when an unsolicited tender offer is the issue. Directors who are elected in this process would not be subject to removal by shareholders acting by written consent, and once elected, they would serve guaranteed threeyear terms, and would be subject to removal without cause only at the next shareholders' meeting.

The appeal of this approach to property model adherents would be that under this structure, long-term institutional investors would have a greater opportunity to elect directors who, in reacting to takeover offers, would be appropriately responsive to stockholder concerns. Thus (it could be argued) these investors should be willing to trust their director-nominees' response to takeover offers, including a decision to "just say no," so long as their response can survive "reasonableness" review under Unocal v Mesa Petroleum Co." This approach should also appeal to the entity modelists, because it would afford the time to corporate boards to implement longer-term plans that may benefit all investors in the corporation's welfare. Thus, the threeyear term would give directors more freedom to focus on the longterm planning that entity model proponents contend is essential to wealth creation than directors with one-year terms would have, particularly if they are also subject to removal by written consent. More fundamentally, the adoption of this approach would strengthen the foundation for the entity modelists' conception of the corporation by giving greater integrity to the corporate election system on which they now base their argument for the legitimacy of director decisionmaking in the takeover context.

The question raised by this discussion proposal is practical: Will both sides of the debate give a little to achieve realistic goals that favor both positions? Are the property modelists willing to live with a system where stockholders must truly engage in the election process outside the tender offer context, and in which the interests of shortterm holders are subordinated? And are entity modelists willing to expose directors to fair election contests on a triennial basis? In our view, it would illuminate the current debate for the contending schools to react to the tradeoff posited here. We advance the proposal simply for the purpose of stimulating such a debate.

In the end, and in our view, only practical statutory ideas of this sort, which have a realistic prospect for embodiment in statutory law, are likely to resolve the debate between the property and entity modelists. If left for resolution by the adjudicative process, the debate will continue with a healthy and appropriate degree of irresolution, because judges will continue to do what they do best-decide specific 
cases in a reasoned and equitable manner, while leaving room for adaptation of the rules to future cases. ${ }^{12}$ Ideal or not, we submit that those who want fundamental change must seek common ground and be willing to compromise if they are to achieve anything in the way of meaningful and concrete legislative reform. ${ }^{13}$

In the pages that follow, we: (1) describe the basic schools of thought, the current state of Delaware law regarding the debate between adherents of those schools, and the reaction of both schools to the current state of the law; (2) examine the property model of the corporation and the problems that limit the likelihood of its being adopted in full by courts; (3) similarly examine the entity model; and (4) flesh out the concept we have summarized above in order to stimulate a more real-world debate between the adherents of both schools.

\section{THE CURRENT STATE OF THE DEBATE}

We first expand on the idea of the conceptual contest over the nature of the corporation. While there are nuances in each of the two contesting models, generally most commentators can fairly be fit into one of these two traditions. ${ }^{14}$ The first camp consists of those who embrace what we call the "property" conception of the corporation, which posits that the purpose of the corporation is the maximization of wealth for the stockholders who own its shares. ${ }^{15}$ The property school strongly believes that capital markets, while not perfect, are generally efficient, and that the overall wealth of society will be enhanced in the long term if corporate control can be transferred rela-

12 The current Delaware approach has many advantages, not the least of which are its flexibility and openness to change, and has produced arguably beneficial results. For a general discussion, see Lipton and Rowe, 27 Del J Corp L (forthcoming) (cited in note 10) (articulating these benefits and the costs of another approach). See also Robert Daines, Does Delaware Law Improve Firm Value?, 62 J Fin Econ 525 (2001) (suggesting that Delaware firms are valued more highly by the capital markets than comparable firms); Leo E. Strine, Jr., Delaware's Corporation Law System: Is Corporate America Buying an Exquisite Jewel or a Diamond in the Rough?, 86 Cornell L Rev 1257 (2001) (defending the virtues of Delaware's approach to corporate law decisionmaking); Jill E. Fisch, The Peculiar Role of the Delaware Courts in the Competition for Corporate Charters, $68 \mathrm{U}$ Cin L Rev 1061 (2000) (discussing the benefits of the policy-intensive role of the Delaware courts making corporate law).

13 Again, we emphasize that the proposal advanced in this Article for discussion purposes does not manifest any personal discontent on our part with the overall results flowing from the current structure of Delaware law. Indeed, our views on the general workability are in accord with those articulately expressed in the paper written for this Symposium by Professors Kahan and Rock. See generally Kahan and Rock, 69 U Chi L Rev 871 (2002). The Kahan-Rock view (that the system is not broken and seems to be functioning well, on balance) is one we share, and we advance the idea we do because it is responsive to an academic debate that is deep-seated, rather than one that is raging in the world outside the academy.

14 See Allen, 14 Cardozo L Rev at 264-66 (cited in note 9).

15 See id. 
tively freely between buyers and sellers. ${ }^{16}$ Through the market, assets will be devoted to their highest and most efficient use, and will produce results whose benefit outweighs any social harm flowing from transfers that turn out badly."

Under this model, the directors' only mandate is to advance the interests of stockholders. Therefore, property model adherents view dimly any exercise of directorial power that interferes with the procession of an "all-shares, all-cash" tender offer once the board has had the opportunity to seek out a better value or convince the stockholders that not tendering is a better choice. ${ }^{18}$ Property modelists are skeptical of claims that corporations ought to be operated to accomplish some purpose other than to profit the current owners of their shares. Property modelists also question the legitimacy of director action designed to further the interests of "other constituencies," who (they say) are adequately protected by contract and statutory law. On what principled basis (they ask) should directors be permitted to advance their own social views at the expense of those who have put their capital at risk as shareholders? In general, the property model's proponents consist primarily of academics and activist investors. Increas-

16 See id at 269.

17 Professor Mark Roe has summarized this argument well:

Shareholder wealth maximization is usually accepted as the appropriate goal in American business circles. The norm makes some uneasy, though: after all, why should shareholders, who usually are favored members of their society, prevail over, say, current employees, who usually are less favored? The utilitarian justification is that this preference is the price paid for strong capital markets, and allocative efficiency and that these benefits are so powerful that they overwhelm the normative benefit of any distributional favoring of current employees over current shareholders. In the long run, the argument goes, employees and other stakeholders are overall better off with fluid and efficient capital markets, managers need a simple metric to follow, and both wealth and, in the end, fairness are maximized by shareholders being the corporation's residual beneficiary, with the other claimants getting what they want via contract with the corporation. Current employees might be made worse off in some industries, but employees overall will have more opportunities, higher salaries, and better working conditions. Furthermore, a stakeholder measure of managerial accountability could leave managers so much discretion that managers could easily pursue their own agenda, one that might maximize neither shareholder, employee, consumer, nor national wealth, but only their own.

Mark J. Roe, The Shareholder Wealth Maximization Norm and Industrial Organization, $149 \mathrm{U}$ Pa L Rev 2063, 2065 (2001).

18 See, for example, Robert B. Thompson and D. Gordon Smith, Toward a New Theory of the Shareholder Role: "Sacred Space" in Corporate Takeovers, 80 Tex L Rev 261, 299-300 (2001) (advocating the recognition of "sacred space" for shareholder decisionmaking, an area within which shareholders can sell their shares free from managerial interference); Ronald J. Gilson and Reinier Kraakman, Delaware's Intermediate Standard for Defensive Tactics: Is There Substance to Proportionality Review?, 44 Bus Law 247 (1989) (discussing the threat of substantively coercive offers and arguing that only time-limited measures are proportionate responses); Lucian Arye Bebchuk, The Case for Facilitating Competing Tender Offers, 95 Harv L Rev 1028, 1029-30 (1982) (arguing that although it is beneficial to society and shareholders alike to facilitate competing tender offers, there are strong reasons to oppose defensive tactics that obstruct an offer). 
ingly, the shareholder wealth maximization principle inherent in the property model is also being acknowledged by members of corporate boards.

The "entity" modelists embrace a contrary perspective. ${ }^{19}$ Rooted in a long tradition, that perspective views the corporation as a societal institution whose purpose is broader than simply serving the ends of those who own stock. This school draws most of its adherents from within the ranks of corporate managers, directors, and transactional planners, with less support from the academy, at least in terms of numbers. ${ }^{20}$ In their conception, all the constituencies that are important to the functioning of the corporation-the employees, the communities in which corporations function, and creditors - are entitled to have their interests considered by boards of directors. In turn, the board is viewed as an intermediating body charged with responsibility for acting as faithful trustees who balance the interests of the constituencies and forge a long-term path that generates the most benefit for all concerned. ${ }^{2 \mathrm{t}}$

Weaker forms of this conception also exist. Those forms, while acknowledging that stockholder wealth maximization is the core purpose of the corporation, emphasize that what is critical is long-term wealth maximization. ${ }^{2}$ The board of directors exists to exercise an informed, good-faith judgment that is independent. The board need not bend to the demands of the current array of stockholders, so long as the directors believe that the corporation's best interests are served by a strategy that the current stockholders may disfavor. Those who hold this view also believe that there is economic value to allowing boards to make these decisions. Those persons view the market that gave us the Enron and dot.com "bubbles" as a very unreliable indicator of true value, and they view the board as an expert body that can chart a

19 See Margaret M. Blair and Lynn A. Stout, A Team Production Theory of Corporate Law, 85 Va L Rev 247, 264-65 (1999) (emphasizing the importance of lateral interaction among team members to the internal governance of corporations).

20 The entity model has recently benefited from articulate and provocative support from Professors Margaret M. Blair and Lynn A. Stout. Although not without its own difficulties, their "team production" version of the entity model of the corporation has the flesh-and-blood richness of real human experience, and therefore advances the discussion about how corporations in fact function to generate wealth in a very useful way. See id at 265-76.

21 See id at 291.

22 Martin Lipton's views over the years have increasingly accepted that the purpose of the corporation is to advance the interests of stockholders who have committed their capital to the firm for a long period of time, if not indefinitely. See, for example, Martin Lipton, Corporate Governance in the Age of Finance Corporatism, $136 \mathrm{U}$ Pa L Rev 1, 38 (1987) (arguing that rational shareholders with a long-term interest in the corporation's prosperity should support a system that provides directors with the flexibility to respond to takeovers). In an earlier, landmark article on takeovers, Lipton advocated a broader constituency view. See Martin Lipton, Takeover Bids in the Target's Boardroom, 35 Bus Law 101, 130 (1979). See also Lipton, 69 U Chi L Rev at 1040 (cited in note 10) (citing his earlier views). 
corporate direction independent of current market fads and whims. ${ }^{23}$ At a deeper level, these commentators also question whether overall wealth will be maximized by allowing willy-nilly takeover activity.

Entity modelists support this view with several arguments. The first is that corporate wealth is not generated solely by stockholders. It is also generated by the corporation's "other constituencies," whose incentives to make "firm-specific" investments will be greatly reduced if those other constituencies believe their contributions can be expropriated unfairly any time the stockholders wish to sell the company at a premium. ${ }^{24}$ The second is that most investors hold a diversified portfolio. Deals may be inadvisable for many reasons, and there is literature that suggests hostile deals do not work out well for the acquiring companies. That is, after a hostile deal, the resulting corporation may in fact generate less wealth as a combined entity than would have been generated by both corporations operating separately or if a different, lower-priced, friendly deal had been consummated. Because stockholders are likely to own stock of potential acquirors as well as stock of potential targets, whatever profits they make from being holders of target stocks are likely to be offset by losses in other parts of their portfolio and also by the overall loss in wealth creation caused by ill-conceived hostile deals.

The entity conception also draws heavily on analogies to the republican form of democracy, wherein elected representatives are chosen and empowered to make decisions for the polity as a whole, using their own judgment, rather than implementing whatever popular policy current public opinion dictates. Indeed, some of its advocates wax almost patriotic about the institution of the board, going so far as to imply that end-running the board is tantamount to a perversion of the corporate republic. ${ }^{25}$

23 See Lipton and Rowe, 27 Del J Corp L (forthcoming) (cited in note 10) (discussing weaknesses in the efficient market theory); Lipton, $69 \mathrm{U}$ Chi L Rev at 1042 (cited in note 10).

24 Blair and Stout, 85 Va L Rev at 272 (cited in note 19), citing Raghuram G. Rajan and Luigi Zingales, Power in the Theory of a Firm, 113 Q J Econ 387, 392 (1998).

25 See Lipton and Rowe, 27 Del J Corp L (forthcoming) (cited in note 10). In this regard, several commentators have pointed out to us that the empirical evidence that hostile takeovers tend to be more beneficial to target stockholders than to the stockholders of the acquiring corporations suggests that property school advocates are overlooking an important concern of stockholders. These advocates focus almost entirely on the rights of stockholders as potential recipients of offers. The empirical evidence can be read to indicate that entity school advocates should be spending more time ensuring that the stockholders of acquirors have comparable protections under state corporation law (for example, the right to approve by vote a wider class of acquisitions). As a historical matter, for example, Paramount Communications, Inc v Time Inc, 571 A2d 1140, 1154 (Del 1990) ("Time-Warner"), turned importantly on the absence of any state law requirement that the stockholders of Time approve its restructured acquisition of Warner.

26 See Lipton and Rowe, 27 Del J Corp L (forthcoming) (cited in note 10). 
The Delaware General Corporation Law does not uncontestably embrace either model. The DGCL gives the board of directors a central role in corporate decisionmaking, ${ }^{27}$ but it also requires stockholder assent for many fundamental transactions. ${ }^{28}$ Most importantly, the DGCL is silent on the most contentious question in the debate between the two schools: in what circumstances, and to what extent, are directors empowered to prevent stockholders from accepting a tender offer? The DGCL does not speak to this question, leaving the significance of that silence for vigorous debate.

That legislative silence is what has prompted the debate in its current form. The property modelists see the statutory vacuum as a purposeful decision to leave room for stockholder choice-as a form of "sacred space" that directors can invade only for carefully limited purposes. ${ }^{29}$ Under that view, stockholders must ultimately be allowed to decide for themselves whether to accept an all-shares, all-cash premium tender offer. ${ }^{30}$ The advocates of this school would have Delaware's judiciary adopt as a matter of fiduciary duty law something akin to the London City Takeover Code.

In stark contrast, the entity modelists regard the statutory silence as inadvertent. They view the DGCL as embodying a clear choice for

27 See, for example, 8 Del Code Ann $\$ 141$ (2001).

28 See, for example, 8 Del Code Ann $\S 251$ (2001) (mergers), $\$ 271$ (2001) (sales of substantially all the assets of the firm).

29 See Thompson and Smith, 80 Tex L Rev 261, 299-300 (cited in note 18); Ronald J. Gilson, A Structural Approach to Corporations: The Case against Defensive Tactics in Tender Offers, 33 Stan L Rev 819, 831-33 (1981) (arguing that statutes merely create a skeleton for corporations); Gilson, 27 Del J Corp L (forthcoming) (cited in note 10).

30 This viewpoint hit its high-water mark in case law with the Court of Chancery's decision in City Capital Associates Limited Partnership v Interco, 551 A2d 787, 798 (Del Ch 1988), which held that a poison pill could only be used for a time-limited period to block stockholders' access to a noncoercive, all-shares premium offer. During that period, the board could seek a higher offer, argue against acceptance of the offer, or develop a higher-value alternative strategy. Id. The Delaware Supreme Court's Time-Warner opinion expressed disapproval of Interco in dictum. See $571 \mathrm{~A} 2 \mathrm{~d}$ at 1153 . The logical force of Interco still resonates in some later decisions, however. See Chesapeake Corp v Shore, 771 A2d 293 (Del Ch 2000); Ace Limited v Capital Re Corp, 747 A2d 95 (Del Ch 1999). This has troubled some in the entity school. See Paul K. Rowe, The Future of the "Friendly Deal" in Delaware at 16, working paper (2001) (on file with authors).

31 Takeover Panel, City Code on Take-Overs and Mergers (7th ed 2002), available online at <http://www.thetakeoverpanel.org.uk> (visited May 3, 2002). That Code requires that stockholders be given the right to accept offers that meet certain specified characteristics designed to ensure fairness and prevent coercion. For an example of this view, see Lucian Arye Bebchuk and Allen Ferrell, Federalism and Corporate Law: The Race to Protect Managers from Takeovers, 99 Colum L Rev 1168, 1193 (1999):

The British regulatory system is an example of a national system of regulation that both addresses possible defects in the takeover process and ensures that shareholders, not management, have the ultimate say on whether a takeover proceeds. It accomplishes this without the degree of uncertainty and pervasive takeover litigation that characterizes U.S. state takeover regulation. 
primacy of director decisionmaking about the future of the entity. As in other areas of consequence to the corporation, the directors are empowered to intervene if they believe that a tender offer is not in the company's best interests. If the directors are acting in good faith and on an informed basis in blocking even an all-shares, all-cash premium bid, they are supreme within their statutory and fiduciary spheres, and their judgment must be respected. Thus, the directors can "just say no.",33

The Delaware judiciary's reaction to this debate has left neither of these schools fully satisfied. As a matter of principle, Delaware case law holds that the purpose of the corporation is to maximize the wealth of its stockholders. ${ }^{34}$ To that extent, Delaware has embraced, in part, the property model. But that endorsement has been tempered by decisions giving directors substantial authority to deploy the powerful weapon of a poison pill ${ }^{35}$ and to block takeover offers that appear to be in the best interests of the current array of stockholders. In such situations, directors may act in the best interests of the corporation over the long term, and to achieve that goal, they may reject a takeover offer favorable to the present holders when the board has concluded that the corporation will generate greater economic returns in the long run under a different strategy. ${ }^{36}$ To this extent, Delaware law inclines towards the entity model. Indeed, it must be acknowledged that to this extent Delaware law affords the directors room to consider the interests of other constituencies (for example, employees and communities) in reacting to takeover bids, although the judicial opinions are careful to downplay this factor.

But the Delaware courts have not given boards a blank check to block takeover bids. Instead, the courts have subjected defensive measures to a heightened form of judicial review under which directors must prove the reasonableness and good faith of their actions. ${ }^{37}$ Over a decade after Paramount Communications, Inc $v$ Time Inc ("Time-Warner"), the extent to which a board of directors with a

32 See Lipton and Rowe, 27 Del J Corp L (forthcoming) (cited in note 10).

33 See id; Lipton, 69 U Chi L Rev at 1046 (cited in note 10).

34 See, for example, Cede \& Co v Technicolor, Inc, 634 A2d 345, 360 (Del 1993) (" $[D]$ irectors are charged with an unyielding fiduciary duty to protect the interests of the corporation and to act in the best interests of its shareholders."); Revlon, Inc v MacAndrews \& Forbes Holdings, Inc, 506 A2d 173, 182 (Del 1986) (addressing the auction context). See also E. Norman Veasey, Should Corporation Law Inform Aspirations for Good Corporate Governance Practices-or Vice Versa?, 149 U Pa L Rev 2179, 2184 (2001) (stating that Delaware law adopts the norm of shareholder primacy).

35 See, for example, Unitrin, Inc v American General Corp, 651 A2d 1361, 1390 (Del 1995).

36 See id; Time-Warner, 571 A2d at $1150 \mathrm{n} 12$.

37 Moran y Household International, Inc, 500 A2d 1346, 1356 (Del 1985); Unocal, 493 A2d at $955-56$.

$38 \quad 571$ A2d 1140 (Del 1990). 
classified board can deploy a poison pill to "just say no" to an all-cash, all-shares premium tender offer still remains a theoretically open issue. ${ }^{39}$ What is established, though, is that an "unclassified" board likely can use a pill to block such an offer, so long as it is possible to remove the board by waging a successful proxy contest. ${ }^{40}$ This other avenue for stockholder choice (director removal) has thus far enabled the Delaware courts to sidestep the pure "just say no" question rather deftly.

Combined with this preference for elections has been a reluctance to expand the scope of the doctrine established in Revlon, Inc $v$ MacAndrews \& Forbes Holdings, Inc, ${ }^{41}$ which requires directors to obtain the best current value reasonably available when they decide to sell the company or engage in a change-in-control transaction. ${ }^{42} \mathrm{By}$ excluding from the reach of Revlon stock merger transactions in which the resulting company will not have a controlling stockholder, the Delaware courts gave boards substantial leeway to confer reasonable bidding advantages upon their preferred merger partners, thereby insulating such transactions from easy disruption from topping bids. This approach to Revlon has also minimized concern that the announcement of a merger of equals puts the parties fully "in play." Although there is some controversy about the intensity of judicial review that should be applied to "deal protection measures" contained in such merger agreements, that controversy has not been about whether Revlon duties should apply. Rather, it simply consists in whether the Unocal "reasonableness" standard of review or the business judgment rule's "rationality standard" should govern the validity of deal protec-

39 It must be remembered that Time-Warner was not a "pill case." 1989 Del Ch LEXIS 77 at $* 1$ (Allen). Years later, the United States District Court for the District of Delaware did issue an opinion leaning towards the validity of the "just say no" option, Moore Corp Ltd v Wallace Computer Services, 907 F Supp 1545, 1557-59 (D Del 1995) (finding that an all-cash, all-shares tender offer may pose a legally cognizable threat if it is inadequate, and therefore justifies reasonable defensive measures), but that decision is nonauthoritative, since the Delaware state judiciary has not yet spoken on the issue. See Ronald J. Gilson and Bernard S. Black, The Law and Finance of Corporate Acquisitions 783 (Foundation 2d ed 1995) (noting that the validity of the "just say no" defense under Delaware law is an open question).

40 Unitrin, $651 \mathrm{~A} 2 \mathrm{~d}$ at 1388; Moran, $500 \mathrm{~A} 2 \mathrm{~d}$ at 1354.

41506 A2d 173 (Del 1986).

42 See Paramount Communications, Inc v QVC Network, Inc, 637 A2d 34, 44 (Del 1994) (explaining the Revlon doctrine).

43 For a discussion by one of us of this area of the law, see Leo E. Strine, Jr., Categorical Confusion: Deal Protection Measures in Stock-for-Stock Merger Agreements, 56 Bus Law 919 (2001).

44 See, for example, Rowe, The Future of the "Friendly Deal" in Delaware (cited in note 30) (advocating business judgment rule-not Unocal-review of such measures). For a different view, see the discussion of the appropriate intensity of judicial review of certain deal protection measures in John C. Coates IV and Guhan Subramanian, A Buy-Side Model of M\&A Lockups: Theory and Evidence, 53 Stan L Rev 307, 382-83 (2000) (concluding that lockups should be subject to close judicial scrutiny). 
tion measures. ${ }^{45}$ Under either approach, boards have the power to grant strong protections to favored partners. ${ }^{46}$

The result is a regime in which directors are given substantialbut not unlimited - authority to forge corporate strategies, while leaving room for stockholders to vote down management-preferred mergers and to use the election process to avail themselves of a tender offer. Substantial areas of uncertainty remain, and the outcome in particular situations can turn on how carefully the company's certificate of incorporation was designed. For example, whether corporate planners included a classified board or eliminated the ability of stockholders to act by written consents in the corporate charter long before a takeover dispute began can determine the outcome of a takeover dispute. Neither model's proponents are comfortable with this feature of the current state of Delaware law.

But while the status quo may be criticized fiercely for lacking doctrinal purity, that shortcoming has hardly stymied mergers and acquisitions activity in the United States. During the fifteen-year period that Delaware law evolved into its current form, the United States experienced a boom in M\&A activity. ${ }^{47}$ Boards of directors became more willing than ever to accept takeover offers and, as important, to seek out strategic mergers that generate premia for their stockholders. Thus, it would appear hyperbolic to characterize the status quo as altogether unacceptable to the property school. And the fact that directors play such an important role in facilitating this M\&A activity would appear to accommodate many of the entity school's concerns as well.

Yet neither school is entirely content. The property school is restless because it sees Delaware law as providing too much room for directors to fend off unwanted offers. Some of its proponents regard Delaware's apparent propensity to funnel all takeover disputes into the election process as inexplicable and empirically unjustifiable. That school hungers for a system that gives stockholders a clear right to decide for themselves whether to accept an all-shares offer, at least

45 We have previously described the distinction between these concepts in the corporate law. See William T. Allen, Jack B. Jacobs, and Leo E. Strine, Jr., Function over Form: A Reassessment of Standards of Review in Delaware Corporation Law, 56 Bus Law 1287, 1296 (2001).

46 See Strine, 56 Bus Law at 927-28 n 25 (cited in note 43).

47 See Lipton, 69 U Chi L Rev at 1053 nn 59-60 (cited in note 10) (citing data); Lipton and Rowe, 27 Del J Corp L (forthcoming) (cited in note 10) (same); Joseph H. Flom, Mergers \& Acquisitions: The Decade in Review, 54 U Miami L Rev 753 (2000) (same).

48 See Gilson, 26 Del J Corp L 492 (cited in note 10); Ronald Gilson and Alan Schwartz, Sales and Elections as Methods for Transferring Corporate Control, Stanford Law and Economics Working Paper No 180 (2001), available online at <http:/papers.ssm.com/id=249067> (visited Apr 30, 2002). 
after certain preconditions are met. ${ }^{49}$ To that end, the property modelists have proposed various legislative solutions, even calling for federal legislation that would mandate stockholder choice.

But the entity school also has its beefs. Although it purports to embrace the current regime, which allows directors to keep antitakeover defenses in place as long the directors comply with their fiduciary duties, that school's proponents often make "Chicken Little" arguments whenever judicial review of directorial action is more than perfunctory. ${ }^{\text {s1 }}$ When courts scrutinize carefully whether directors have acted reasonably under Unocal in specific cases, this school tends to (somewhat hyperthyroidally) predict the end of the world as we know it.

But rather than being practical about the resolution of their differences, the two schools have opted for ideological purity, talking past each other and never really seeking out common ground. And as we next point out, by adhering to its current perspective, neither school is likely to have its view adopted in full by judges forced to decide between them without clear legislative guidance.

49 Some property modelists accept the proposition that elections are a less coercive and therefore more reliable method of stockholder decisionmaking regarding tender offers. Lucian Bebchuk's Article in this Symposium reflects that position. See Bebchuk, 69 U Chi L Rev 973 (cited in note 10). See also Lucian Arye Bebchuk and Oliver Hart, Takeover Bids versus Proxy Fights in Contests for Corporate Control, Harvard Olin Discussion Paper No 336 (2001), available online at $<\mathrm{http} / /$ papers.ssrn.com/id=292883 $>$ (visited May 3, 2002). These scholars, however, are opposed to the idea that a poison pill can be used by a majority of a classified board to block a tender offer once stockholders have voted to elect the pro-tender-offer slate in a corporate election. See Bebchuk, 69 U Chi L Rev at 975-76 (cited in note 10); Lucian Arye Bebchuk, John C. Coates IV, and Guhan Subramanian, The Anti-Takeover Power of Classified Boards: Theory, Evidence, and Policy, 54 Stan L Rev (forthcoming 2002).

50 See, for example, Lucian Arye Bebchuk and Allen Ferrell, A New Approach to Takeover Law and Regulatory Competition, 87 Va L Rev 111, 152 (2001) (advocating the adoption of federal takeover rules that would allow shareholders to opt out of state law); Samuel C. Thompson, Jr., Change of Control Board: Federal Preemption of the Law Governing a Target's Directors, 70 Miss L J 35, 35-36 (2000) (proposing a uniform federal standard governing the conduct of a target corporation's board of directors).

51 By this reference, we do not embrace the views of those who believe that judicial review under, for example, the Unocal standard is toothless. While Delaware courts do not lightly set aside director action under that standard, they have done so, and (if past is prologue) will likely do so in the future. Our sense is that this form of more searching ex post review tends to cause transactional planners to adopt weaker defenses ex ante.

52 See R.E.M., It's the End of the World as We Know It (and I Feel Fine), on Document (IRS Records 1987). The classic example is Martin Lipton's famous client memorandum in the late 1980 s advocating consideration of redomiciliation outside Delaware in response to Interco. See Laurie P. Cohen, Lipton Tells Clients that Delaware May Not Be a Place to Incorporate, Wall St J B7 (Nov 11, 1988). For a more recent example, see Rowe, The Future of the "Friendly Deal" in Delaware (cited in note 30 ). 


\section{A WISE AMBIVALENCE? WHY NEITHER MODEL IS LIKELY TO EMERGE AS EXCLUSIVELY PREDOMINANT IN MODERN CORPORATION LAW}

The advocates of the property and entity models have generated a rich body of writing, fairness to which would require a more extended and nuanced critique than space permits us to advance here. For present purposes, we simply note some features of each model that reduce the likelihood of wholesale judicial adoption of either model as an overarching framework for decisionmaking in corporation law cases. Our intent is not to be exhaustive. Rather, it is to highlight certain issues that are likely to be on the minds of judges confronting arguments premised on either or both models.

\section{A. The Property Model}

Three important problems would concern judges confronting shareholder choice arguments premised on the property model. Those problems, absent statutory reform, would likely prevent the property model from being embraced in its totality.

The first feature, which is a strength of the property model, is also perhaps its most significant weakness in terms of its appeal to judges asked to make a policy-based decision in reliance upon it. The property model has a ruthlessly narrow focus that some view as overly simplistic and insufficiently attentive to other human values. Judges presented with takeover cases are unavoidably aware that the interests of more than stockholders are usually at stake. The property model tends to ignore that reality. The only solace it offers is that over the long term, the societal benefits of unrestricted corporate control transfers will greatly exceed any pain caused to particular institutions or persons from ill-advised takeovers.

In a real sense, the property model tends to reduce societal institutions of great importance to a form of currency, and to render irrelevant considerations that are of great social significance. Corporations usually do not become successful overnight. To enable the corporation to reach its current value, decades of investment are often required from employees, creditors, and communities. Investors of capital, who are the heroes of the property conception, are seen in this view as the constituency with the most transitory form of investment in the corporation. For public companies at least, exit is fast and lowcost. But the investment of employees and communities is quite dif-

53 In fairness, some scholars, for example, Professor Ronald Gilson, acknowledge these issues but conclude that deference to stockholder choice will, on balance, better advance social welfare. See Gilson, 27 Del J Corp L (forthcoming) (cited in note 10). 
ferent. Those constituencies depend on the corporations' ongoing business activity. Even for-profit corporations may play important and useful roles in the cultural and political life of our society, roles that can be threatened by a change in corporate policy forced by a hostile takeover.

It should be expected that judges will be uncomfortable handing down orders that displace decisions of directors affecting the future of such corporate institutions. A market-based approach would result in allowing the momentary best interests of an array of short-term stockholders to trump all other considerations at any point in time by causing a sale of the corporation for a one-time profit. The consequence is an unsurprising concern that a wholesale adoption of this approach would invariably subjugate the interests of other corporate constituencies to the interests of short-term traders, and thereby defeat the legitimate expectations of those other constituencies.

These concerns are exacerbated by a second problem: namely, the uncertainty over whether the property model is, in fact, the corporate law system that will best facilitate the maximization of societal wealth. While the theory is clear enough, its empirical support is not unequivocal. Nevertheless the property modelists display great certitude. They seem to give little credit to the fact that directors have much greater access to information flows respecting business prospects and values. Stockholders are seen as competent to make a rational decision about what deal offers the best value for them, short-

54 For example, one of us wonders whether arguments based on the unique and economically valuable corporate culture of, say, Dairy Queen or Foot Locker would have been as easily accepted as were the arguments based on the culture of Time in the Time-Warner case. As a matter of practical reality, one would suspect that the fact that the case involved the future of a magazine considered culturally significant must have played some role in the adjudication that was more than purely economic.

55 Some scholars urge that the empirical data clearly demonstrate that target stockholders are benefited by a stockholder choice regime. See Gilson, $27 \mathrm{Del} J$ Corp L (forthcoming) (cited in note 10). For our purposes, we need only make two points. First, talented advocates of the entity school such as Lipton can, at the very least, fashion plausible-sounding arguments to the contrary, making this question a difficult one for a court to answer reliably. Second, the empirical data that stockholders with diversified portfolios benefit from a stockholder choice system are less clear, as scholars such as Professor Gilson implicitly acknowledge. See id; James A. Fanton, Braking the Merger Momentum: Reforming Corporate Law Governing Mega-Mergers, 49 Buff L Rev 249, 251, 256-57 (2001) (summarizing evidence that in Fanton's view supports the conclusion that many mega-mergers result in value destruction). Moreover, these scholars acknowledge that the extraction of higher premia for target stockholders does not necessarily benefit overall social welfare, which is somewhat of a concession to the entity school's viewpoint. See Bebchuk, $69 \mathrm{U}$ Chi L Rev at 1020 (cited in note 10) (arguing that from the perspective of overall shareholder wealth, the extraction of a higher premium from the bidder is merely a transfer).

56 Professor Gilson acknowledges this factor, but argues that the dangers posed by board incentives to act defensively in ways that are adverse to stockholder interests are greater, for which reason a system of stockholder choice is, on balance, preferable. Gilson, 27 Del J Corp L (forthcoming) (cited in note 10). 
term. The larger question, however, is whether shareholders have sufficient information and appropriate incentives to determine, equally or more competently than directors, whether the corporation should be sold at all, or should consummate a different extraordinary transaction, when the board disagrees with that strategic direction.

There is also reason to question whether it makes sense to allow long-term strategies set by boards to be subject to displacement whenever a noncoercive premium offer to acquire the company materializes. Is there not some social value in allowing the board to adhere to its strategic game plan until fruition, without the nuisance of fighting off intermittent plebiscites?

In considering this question, one must distinguish between the interests of a short-term stockholder who has bought into a stock after hearing of takeover rumors and the interests of a hypothetical investor who has entrusted his capital to the corporation for an indefinite and lengthy period of time. A merger deal that would satisfy the former may not satisfy the latter because it could diminish the corporation's ability to deliver higher long-term returns. These arguments are not without intuitive appeal, and perhaps even empirical validity, and judges are sensitive to them.

The empirical uncertainties associated with the property model dovetail with the normative shortcomings of the model earlier identified. Together they argue persuasively for judicial deference to director decisionmaking in this area. The moral or ethical claim of equity holders of entitlement to force a sale against the good-faith, informed judgment of the board is far from self-evident. Equity holders, to be sure, undertake significant economic risk, but so too do other corporate constituencies, particularly rank-and-file employees. Why should the corporate governance system be structured to allow the equity holders' interests to prevail at the expense of other constituencies when the directors who were elected by the stockholders themselves do not believe that the stockholders' preferred outcome is desirable?

The fact that there are arguments that the property model provides to answer this question does not remove it from the practical environment of some judicial thinking. And it is credibly arguable that an approach that locates these decisions in the hands of directors elected by the stockholders, with no involvement by other constituencies, is an efficacious way to recognize stockholder primacy as a focus of board concern, while at the same time tempering the adverse effects on other constituencies that would result from authorizing the current stockholders to sell the corporation whenever they may desire.

Third, in Delaware and jurisdictions having similar comparable statutes, the property model confronts a structural barrier that would 
preclude its wholesale incorporation into fiduciary duty common law. To use Delaware as an example, the existing corporate jurisprudence developed by the Delaware courts is arguably a logical outgrowth of the statutory framework. The DGCL is structured, one could argue, to preclude equity investors from having a legally enforceable expectation of entitlement to sell the corporation without board assent. The reason is that under the statute, almost every significant corporate transaction requires board approval. ${ }^{57}$ Although we take no position on whether the DGCL's failure to address tender offers can be attributed to historical timing, ${ }^{s s}$ we recognize the cogency of the argument that if the statutory drafters had foreseen the impact of hostile tenders offers upon corporate governance, the board's role in approving such offers might have found its way explicitly into the statute, rather than through later judicial interpretations of director authority."

Against the backdrop of this statutory structure, cases such as Moran $v$ Household International, Inc ${ }^{60}$ and Unocal upheld the primacy of directorial power in this area over fifteen years ago, leaving open only issues concerning the proper exercise of that authority in specific circumstances. At no time has a serious legislative initiative been proposed in Delaware (or elsewhere, to our knowledge) that would erode the basic proposition that directors have the power to defend actively against hostile takeover proposals. In Delaware, the exercise of that power is subject only to judicial review of the reasonableness of their actions. And in several other jurisdictions, judicial review is based on the more lenient business judgment standard. ${ }^{6}$

57 See Lipton and Rowe, 27 Del J Corp L (forthcoming) (cited in note 10); Michael P. Dooley, Two Models of Corporate Governance, 47 Bus Law 461, 468 (1992). To the extent that stockholders' claim of empowerment to cause the sale of the entity is weak, the other constituencies' expectancy that the entity will be sold only when the board determines to do so becomes correspondingly stronger. See Blair and Stout, $85 \mathrm{Va} \mathrm{L} \mathrm{Rev} \mathrm{at} 285$ (cited in note 19) (indicating that other constituencies make firm-specific investments at least in partial reliance on the board's role as a mediating hierarch).

58 The last comprehensive revision of the DGCL came in the late 1960s, a time when the use of tender offers as a method to accomplish a hostile takeover was rare to nonexistent.

59 We also recognize that there is a potent argument to the contrary. That argument has been stated with more elegance by others elsewhere, most notably by Professor Gilson. See Gilson, 26 Del J Corp L at 508-09 (cited in note 10); Gilson, 27 Del J Corp L (forthcoming) (cited in note 10). The gist of this reasoning is that the failure of the DGCL to require director approval of tender offers should be viewed as deliberate, leaving this area as one in which stockholders are free to make their own decisions. See Gilson, 26 Del J Corp L at 508-09. Under the doctrine of independent legal significance, the tender offer method of acquisition should be accorded equal respect as a legally authorized method of proceeding with an acquisition, separate and apart from a merger addressed by specific provisions of the DGCL, such as 8 Del Code Ann $\S$ 251. Id. Indeed, Gilson argues that the tender offer process is a safety valve that permits boards responsibly to be given veto power over mergers and asset sales. Id.

60500 A2d 1346 (Del 1985).

61 See Lipton, 69 U Chi L Rev at 1049 n 49 (citing examples); Lipton and Rowe, 27 Del J Corp L (forthcoming) (cited in note 10) (same). 
Given the director-centered approach of American corporation law, the market-centered property model places courts in a somewhat anomalous position. In most areas of corporate decisionmaking, corporate directors who have no conflicting self-interest may adopt corporate policies with little fear of their transactional decisions being enjoined. The property model asks judges to deviate from this practice in the unique area of tender offers. The question becomes: on what principled basis?

There are strong reasons for treating a board decision to resist a tender offer differently from a decision to pursue a new product line. Nonetheless, as a real-world matter, courts are cautious about enjoining action by corporate boards. We reject the notion that an injunction preventing the board's continued deployment of a poison pill would involve the courts displacing boards by "picking which deal is best." We do submit, however, that an approach mandating courts to issue injunctions that require boards to permit stockholders to choose between competing transactions in any and all circumstances would prevent informed, well-motivated boards from opposing transactions that they believe would injure the welfare of the corporations they serve. Courts will not lightly supplant directors who have been elected to manage the corporation. And even when the question is viewed in (the more apt) terms of where the regulatory power of the board ends and the power of the stockholders begins, ${ }^{63}$ courts are unlikely to articulate rigid bright lines that will satisfy transactional planners or the adherents of the property model.

In any event, and as previously noted, the debate on this issue has been settled, at least to the extent that courts do permit-if not require-target company directors to play an active and engaged role in confronting tender offers directed to their stockholders. Although advocates of the property model favor aggressive board action designed to increase the value of bids and protect stockholders from coercively structured bids, ${ }^{4}$ the problem for courts is that once it is recognized

62 A recent article by one of the authors describes some of these reasons and cites to other literature bearing on the subject. See generally Strine, 56 Bus Law (cited in note 43). Lucian Bebchuk's article in this Symposium also sets forth the grounds for making this distinction. See Bebchuk, 69 U Chi L Rev at 996 (cited in note 10).

63 See generally Strine, 56 Bus Law 919 (cited in note 43); Thompson and Smith, 80 Tex L Rev 261 (cited in note 18); Gilson, 33 Stan L Rev 819 (cited in note 29); Gilson, 27 Del J Corp L (forthcoming) (cited in note 10).

64 Their thinking recognizes the possibility for genuine coercion by particular forms of tender offers, as well as the utility of having the board serve as a negotiator for the disaggregated stockholders. See, for example, Bebchuk, 95 Harv L Rev at 1045 (cited in note 18) ("Premiums are raised in unfriendly takeovers in which management actually seeks competing offers, and in negotiated acquisitions in which management . . . bargain[s] for increased premiums."); Gilson and Kraakman, 44 Bus Law 247 (cited in note 18) (observing that coercive bids of various kinds pose a threat that justifies proportionate defensive responses). 
that directors are empowered to intervene, delimiting the scope of that authority by a simple bright-line test is not easy.

Some property model advocates believe that corporate elections are preferable to tender offers as the method for obtaining a free expression of the stockholders' wishes regarding whether to accept a takeover bid. ${ }^{\text {ss }}$ Although that argument provides some support for the current Delaware approach, it does not satisfy these advocates, because the results in particular cases will vary depending upon the corporation's charter, specifically, the reality that many corporations have classified boards. In such cases, those advocates would have the courts require the board to redeem the poison pill once the proponents of a tender offer have won any election focused on the offer, even if the election only replaces a minority of the board. ${ }^{66}$ The problem with this approach is that it puts a court in the position of overriding a board majority, when the presence in the certificate of the classified board structure itself represents a statutorily authorized expression that stockholders may be forbidden from changing the company's strategy in a single election.

For all these reasons, the desire of property model advocates for rules that would require that certain types of bids be submitted to stockholders without board involvement is unlikely to occur as a matter of judicial decisionmaking or at the state statutory law level. ${ }^{67}$ Even less likely are federal changes that would superimpose this species of mandated shareholder choice upon the largely state-governed American system of corporate law. Many members of Congress come from states with constituency statutes that codify the entity model in its strongest form. Delaware law, on the whole, is far more stockholderfriendly than the law of most states. It is unlikely, therefore, that a fed-

65 Bebchuk, 69 U Chi L Rev 975 (cited in note 10); Bebchuk, Coates, and Subramanian, 54 Stan L Rev (forthcoming) (cited in note 49).

66 Bebchuk, Coates, and Subramanian, 54 Stan L Rev (forthcoming) (cited in note 49) (arguing that if a classified board structure was not adopted after 1990, the board should have to redeem the pill whenever an election focusing on a tender offer has resulted in a victory for the pro-tender-offer state); Bebchuk, 69 U Chi L Rev 975 (cited in note 10) (same).

67 We express no position on one of the other methods for advancing the cause of stockholder choice over tender offers, which is through the submission of stockholder bylaw proposals requiring the redemption of a poison pill. That is an open question of Delaware law. See General Datacom Industries, Inc v State of Wisconsin Investment Board, 731 A2d 818, 821 n 2 (Del Ch 1999). Scholars have taken different views on the issue. Compare Lawrence A. Hamermesh, Corporate Democracy and Stockholder-Adopted By-Laws: Taking Back the Street?, 73 Tulane L Rev 409, 415-17 (1998) (arguing that such bylaws are not valid), and John C. Coates IV and Bradley C. Faris, Second-Generation Shareholder Bylaws: Post-Quickturn Alternatives, 56 Bus Law 1323, 1326 (2001) (same), with Jeffrey N. Gordon, "Just Say Never?": Poison Pills, Deadhand Pills, and Shareholder-Adopted Bylaws: An Essay for Warren Buffett, 19 Cardozo L Rev 511, 549 (1997) (arguing that such bylaws should be considered valid), and Gilson, 26 Del J Corp L at 507 (cited in note 10) (same). 
eral statutory approach would favor the property model over the entity model of the corporation.

\section{B. The Entity Model}

Like the stockholder-primacy model, the entity model has limitations that are likely to give pause to judges being asked to adopt that model in its totality as a matter of judge-made law.

In its strongest form, the entity model envisions stockholders as only one of several coequal constituencies whose different interests a board may normally consider when making decisions. One weakness of the strongest form of the entity model is that businesses are ordinarily formed to reap a profit for their stockholders, not to benefit other constituencies. The fair treatment of other constituencies might be instrumentally useful in creating shareholder wealth, but is unlikely to have been the reason why most businesses were established. Moreover, there is force to the view that other constituencies normally protect themselves through contract, and that their interests are also safeguarded by specific aspects of statutory law. ${ }^{69}$ Consequently, it is argued, subject to these contractual and statutory constraints, stockholders and other constituencies should expect that corporations will be operated to maximize the returns for the owners of the corporation's equity. These arguments pose formidable obstacles to proponents of the entity model, who believe that the interests of other constituencies should be accorded equal dignity with the interests of stockholders.

In Delaware, the DGCL statutory framework also makes it difficult for judges to give significant weight to the concerns of other constituencies. The DGCL reflects an overriding concern for the protection of equity holders, and little, if any, concern for non-equity-holder constituencies. ${ }^{70}$ That statutory framework naturally inclines Delaware judges to place stockholder interests at the forefront of their jurispru-

68 See Lipton and Rowe, 27 Del J Corp L (forthcoming) (cited in note 10) (noting that a majority of states has adopted a constituency statute). See also Bebchuk, Cohen, and Ferrell, 90 Cal L Rev (forthcoming) (cited in note 2) (noting the strength of many states' antitakeover statutes).

69 The workplace safety, unemployment insurance, and fraudulent conveyance laws are examples of protections of this kind.

70 One other factor limits the appeal of the entity approach: to the extent that directors can justify their actions by reference to a broad array of constituent concerns, the (already challenging) judicial task of deciding whether defensive actions potentially influenced by director selfinterest are legitimate could become untenably difficult. As Professor Kahan commented to us, many property modelists believe that the entity modelists are more aptly labeled as managerialists. These skeptics suggest that managers often cloak self-interested, entrenchment concerns in high-minded rhetoric about long-term stockholder value and (in at least some states) the interests of other constituencies. 
dence, and provides the courts with little room to advance other interests, except when those interests coincide with the goal of maximizing stockholder wealth."

The entity model also labors under the same empirical uncertainties that afflict the property model. Because the proposition that a strong entity model is economically superior has yet to be proven, judges would be worried that the wholesale adoption of the entity model could diminish the overall wealth-creating potential of the corporate form. The basis for that concern is that if equity investors do not have the assurance that their interests will be placed at the head of the line, less capital might flow into the markets, thereby diminishing economic growth. In the long run, the social costs occasioned by the reduced incentives for investment would (it is argued) far outweigh any social costs incurred by other constituencies affected by takeovers. Put differently, in the long run, the interests of workers and communities are aligned with the interests of investors.

Even if the premise of stockholder primacy is accepted (as the weaker form of the entity model accepts it), that model has other problems. Property model advocates argue that economic growth is best facilitated by allowing assets to flow to those who will pay the highest values, and that even if markets are not perfect, they are efficient and should not be impeded by board directors seeking to block noncoercive offers. The entity model rests at least to some extent on the proposition that the efficient market theory is in large measure simply wrong, and that directors are better positioned than stockholders to make decisions about takeovers. These propositions are, of course, debatable. The notion that stockholders cannot make informed decisions about what will best serve their own self-interest is also undercut by two realities: (1) emerging market developments, including the easy availability of higher-quality information about companies, and (2) the emergence of active institutional investors who can bring a longer-term perspective to bear in voting and in responding to tender offers. Given these realities, what is the empirical basis for the asserted need to protect stockholders from themselves?

The entity model's proponents recognize the difficulty with the argument that directors are better positioned to predict what response to a tender offer will best serve the self-interest of the stockholders to whom the offer is addressed at that point in time. To overcome that dif-

71 In Unocal, 493 A2d at 955, the Court indicated that a board's decision to block a tender offer could be based on the "impact on 'constituencies' other than shareholders (i.e., creditors, customers, employees, and perhaps even the community generally)." Revlon, 506 A2d at 176, cut back on this language by establishing that "while concern for various corporate constituencies is proper when addressing a takeover threat, that principle is limited by the requirement that there be some rationally related benefit accruing to the stockholders." 
ficulty, the entity model proponents advance two alternative arguments.

The first argument is that stockholders with diversified portfolios will be better served if informed directors are permitted to block business combinations that they believe in good faith are ill-advised. Overall (the entity model proponents say), stockholders are advantaged if directors are left free to chart a long-term course that focuses on the wealth production of the entities they govern, rather than being forced in all cases to capitulate to the short-term interests of the current equity holders. Because sophisticated stockholders are as likely to own shares of acquirors as of targets, they are as likely to be injured by, as to benefit from, a mispriced deal. Likewise, when a profitable company is sold to an overleveraged financial buyer whose plans eventually put the company into bankruptcy, its current stockholders may reap a one-time premium, but society as a whole suffers the potentially far greater loss of a productive entity. ${ }^{n}$

From a jurisprudential perspective, this argument's main weakness is that it is purely theoretical: it does not speak to any specific case brought before a court. That is, the argument may address the best way to govern the corporate system as a whole, but it does not help a court decide whether a particular corporate board is acting in the best interests of its stockholders in specific factual circumstances.

The second argument is more specifically focused on particular corporations, but involves a degree of temporal uncertainty that also limits its utility as a tool for judicial decisionmaking. The argument is that directors must be permitted to chart a course for the corporation that will generate the most stockholder value, not in the immediate year, but over some longer and often unspecified time horizon. Therefore, a board should be permitted to reject an offer that the marketplace favors, on the basis that an alternative corporate strategy (such as, for example, the continuation of the company as a stand-alone entity under its existing business plan) will deliver greater value over time. Under this system, the only proper role for the court is to address whether the directors are acting in good faith to advance the best interests not of the current stockholders, but of a hypothetical group of shareholders who have committed their capital to the firm for an undefined, but lengthy, time period.

72 Lucian Bebchuk's article for this Symposium illustrates our large point about the tendency of the schools to talk past each other. Bebchuk stresses the empirical evidence supporting 'his view that freer access to takeover offers is likely to increase the wealth of target stockholders qua target stockholders. Bebchuk, $69 \mathrm{U}$ Chi L Rev at 993, 1004, 1009-10 (cited in note 10). He ignores the question of whether investors with diversified portfolios will benefit from the regime he advocates, because his focus is solely on what regime will best serve stockholders whose companies receive takeover proposals. 
The difficulty with this argument is that it requires the court to credit factual assertions that, at times, border on the celestial. It is predictable that courts will give independent directors the benefit of the doubt when the marketplace values their proposed strategy as being within the range of a competing offer. But the issue is more problematic when the marketplace regards the directors' valuation of its strategy as markedly over-optimistic, as when another option (such as a competing bid) has a much higher current market value. In such circumstances, it is difficult for a court to determine whether a board's view that a "premium" offer is inadequate is based on sound financial and business reasoning.

That uncertainty is accentuated where there is reason for concern that the interests of directors and managers may not be totally aligned with those of even long-term stockholders. ${ }^{73}$ Coming from the mouths of corporate directors and managers, arguments that a high-premium offer should be rejected in favor of a different strategy that the market does not endorse can be perceived as a self-serving justification for perpetuating the directors' control or strategic vision, and as all too easy to "gin up." Judges suspect that it is relatively easy for management to hire an investment banker and to coax a CFO to crank up earnings projections that will justify the board's rejection of a higherpriced takeover offer in favor of continuing the status quo or approving a lower-priced friendly deal. ${ }^{74}$ Moreover, directors do not have to pay the price if their projections that their preferred strategy will produce results better for stockholders than a premium bid turn out to be wrong. ${ }^{75}$ The aftermath of two of the more prominent adjudicated

73 The increasing prevalence of independent directors is certainly useful, but the performance of independent directors in other areas of decisionmaking gives stockholder primacy advocates reason to question just how effective this device is as a method for protecting their interests. Recent commentary suggests that independent directors have not performed well in the area of executive compensation. See, for example, Randall S. Thomas and Kenneth J. Martin, Litigating Challenges to Executive Pay: An Exercise in Futility?, 79 Wash U L Q 569, 578 (2001); Lucian Arye Bebchuk, Jesse M. Fried, and David I. Walker, Managerial Power and Rent Extraction in the Design of Executive Compensation, $69 \mathrm{U}$ Chi L Rev 751 (2002).

74 Without pointing to any particular examples, we note that our collective experience is consistent with the proposition that it is generally possible to hire a financial advisor of some repute to provide a favorable fairness opinion or expert testimony in almost any situation. The flexible principles governing the art of valuation allow for this possibility, a reality that Delaware judges face on a constant basis in appraisal cases, which often involve a battle of highly qualified experts who deploy supposedly identical methodologies to come to widely disparate results. Scholars have also developed empirical evidence that tends to undermine the reliability of investment banker opinions. See Bebchuk, $69 \mathrm{U}$ Chi L Rev at $1005 \mathrm{n} 85$ (cited in note 10) (citing these studies).

75 In a recent case, the Court of Chancery noted this reality, stating:

[C]orporate boards that rely upon substantive coercion as a defense are unwilling to bear the risk of their own errors. Corporate America would rightfully find it shocking if directors were found liable because they erroneously blocked a premium tender offer, the company's 
cases where directors were permitted to block a high premium bid make the point. In neither case did the target board's view of longterm value pan out for the stockholders. Thus, as an empirical matter, it is far from settled that directors are equipped to make predictions of this type with reliability."

For these reasons (and absent contrary legislation), decisions by directors to block tender offers will likely continue to be subjected to a more searching form of judicial review. When the Delaware courts in Moran permitted boards to use poison pills to resist unsolicited offers, they were mindful that they were filling in a statutory gap. To safeguard the integrity of the directors' deployment of that authority, the courts protected stockholders by subjecting the use of the pill to heightened scrutiny. ${ }^{78}$ The original insight in Unocal that justifies this more intensive form of review - that when directors and managers face displacement by an offer they did not solicit, a variety of human emotions can potentially compromise their ability to respond to that offer impartially ${ }^{79}$-is one that will probably continue to resonate with judges. Wholly apart from the natural desire of full-time executives to maintain their positions, most directors are individuals of substance and achievement who take pride in what they do. Such persons can be expected to take umbrage when it is suggested (by hostile bidders) that they could be doing their job better.

Absent a statutory mandate, it is therefore unlikely that decisions by directors to defend against an unsolicited bid will be examined by courts under the deferential business judgment standard, which is

shares went into the tank for two years thereafter, and a court held the directors liable for the investment losses suffered by stockholders the directors barred from selling. But, because directors are not anxious to bear any of the investment risk in these situations, courts should hesitate before enabling them to make such fundamental investment decisions for the company's owners. It is quite different for a corporate board to determine that the owners of the company should be barred from selling their shares than to determine what products the company should manufacture.

Chesapeake Corp v Shore, 771 A2d 293, 328 (Del Ch 2000).

76 In Time-Warner and Moore, boards were permitted to reject offers on the grounds that another strategy would produce better value for the stockholders. Moore Corp Ltd $v$ Wallace Computer Services, 907 F Supp 1545, 1559 (D Del 1995); Time-Warner, 571 A2d at 1153-54. The post-decisional performance of the target companies did not prove the directors correct. See Gilson, 27 Del J Corp L (forthcoming) (cited in note 10) (describing poor results for Time stockholders); Thompson and Smith, 80 Tex L Rev at 316 n 259 (cited in note 18) (discussing similarly poor results for Wallace shareholders).

77 Many of these concerns are also noted by Bebchuk, $69 \mathrm{U}$ Chi L Rev at 1001 (cited in note 10).

78 See Moran, 500 A2d at 1356-57 (requiring directors to show that a defensive mechanism is reasonable in relation to the threat posed).

79 See Unocal, 493 A2d at 954 ("Because of the omnipresent specter that a board may be acting primarily in its own interests, rather than those of the corporation and its shareholders, there is an enhanced duty which calls for judicial examination at the threshold before the protections of the business judgment rule may be conferred."). 
what entity model proponents truly desire. Rather, directors' actions are likely to be scrutinized more intensively under the Unocal reasonableness standard of review. It also is doubtful that courts will establish a bright-line precedent that gives boards carte blanche to "just say no." Rather, boards will continue to be subjected to a probing casespecific review in which the court will adjudicate the propriety of the board's reasons for saying no.

The most compelling retort of the entity model advocates to criticisms of that model's emphasis on director decisionmaking rests in its analogy of the corporation to a republic, in which managers are elected to make decisions independently, not to follow directions from the stockholders. Between elections, stockholders are largely passive and lack the affirmative power to force the corporation to undertake a merger or sale without prior board approval. ${ }^{81}$ The notion that stockholders should have the power to disrupt the functioning of the republic whenever they see fit is viewed as fundamentally inconsistent with the Delaware model of the corporation. Delaware law's preference for proxy contests as a way to resolve takeover disputes is viewed consistent with that model, because the election of directors is the one area in which stockholders may act affirmatively. Thus (the entity model advocates would say), for courts to expand the shareholder franchise by allowing shareholders to choose directly whether to accept or reject a tender offer would disrupt the structural balance of power contemplated by the DGCL.

The normative appeal of this analogy to republican democracy is limited, however, by the realities of the corporate election process. One fundamental reality is that the annual election process is tilted heavily towards management and does not operate in a way that encourages genuine choice or debate. Only management's slate may spend the company's money to solicit proxies; outsiders must bear their own costs, which are not trivial.

As a result, the corporate election system for the most part now functions vigorously only when the election contest, mounted by the hostile bidder to replace the incumbent board, amounts to a referendum about a pending tender offer bid. ${ }^{8}$ In that specialized context, the

80 Time-Warner, 1989 Del Ch LEXIS 77, after all, involved an intensive review by the Court of Chancery into the reasonableness of the Time board's action, a review far more exacting than business judgment review.

81 As we touch upon in other aspects of this article, the particular provisions of a company's certificate and bylaws may alter this reality. When directors can be removed by written consents of the stockholders between meetings, a company is open to a hostile takeover at virtually all times.

82 See Lipton and Rowe, 27 Del J Corp L (forthcoming) (cited in note 10).

83 The most articulate proponents of the entity school concede this. See Blair and Stout, 85 Va L Rev at 310 (cited in note 19) ("In both theory and practice ... shareholders' voting 
tender offeror funds the costs necessary to present its own slate, thereby evening the odds that normally favor management.

The consequence of this reality for the "republican democracy" corporate model is that the election process-the source of legitimacy for director decisionmaking in the takeover context-functions effectively only when the election is in fact a takeover contest. Thus, the preference for elections over tender offers comes down to an empirical debate about which is the fairer method for stockholders to choose whether to accept a tender offer, or to the simple expression of a normative preference for greater barriers to hostile takeovers. By this latter statement, we mean that forcing takeover decisions into the election process, more often than not, benefits the incumbent board from a defensive standpoint by subjecting bidders to potentially formidable timing barriers that may render a hostile bid economically impractical. In theory, a staggered board will deter some takeovers altogether because of the delay, risk, and cost that it may impose. In practice, such a defense has not been fatal to all hostile assaults, but it is reasonable to assume that it has deterred some not insignificant number of such efforts. $^{85}$

It is arguable that because most boards in office at the time a contested takeover is initiated have likely never been subjected to a genuine election contest, the incumbent board is less able to draw on a reservoir of stockholder support. In practical terms, what stockholders likely care most about is a board's success in generating profitable results, rather than the fact that the board was elected fairly. But the present election system makes it impractical for stockholders to discipline bad or underperforming management directly through the ballot box. Indeed, property modelists argue that an unconstrained takeover market is useful precisely because it provides a mechanism to replace ineffective management, and thus prods all corporate managers to perform up to their capabilities. Because the current election system is of little utility as that kind of disciplinary tool, the normative case for deferring to the incumbent board's judgments in the takeover context

rights ... are so weak as to be virtually meaningless."). See also Martin Lipton and Steven A. Rosenblum, $A$ New System of Corporate Governance: The Quinquennial Election of Directors, 58 U Chi L Rev 187, 230 (1991) ("Corporate elections therefore tend to produce a realistic challenge to incumbent directors only in the context of takeover battles."). Blair and Stout, 85 Va L Rev at 288-89 (cited in note 19), actually applaud the weakness of the current election system because it insulates the board as a mediating hierarch from too much pressure from the stockholder constituency, giving more room for the board to take account of other interests.

84 See Bebchuk, Coates, and Subramanian, 54 Stan L Rev (forthcoming) (cited in note 49) (demonstrating the mechanism by which an effective staggered board may delay and defeat a hostile bid, and providing examples).

85 Recent scholarship suggests that an effective classified board is the most potent defensive weapon available (when combined with a poison pill) and can be used to make a hostile takeover fight quite unattractive for all but the most hearty of acquirors. Id. 
is weakened. Stated bluntly, when stockholders are told that the board is blocking a bid for their own good, the shareholders may be less than confident that the board - which they had no real choice in electinghas their best interests at heart.

\section{Is There a Principled Way to Bridge the Gap between These Models?}

These, we believe, are some of the reasons why Delaware law has not adopted in toto either of these competing models of corporate governance as the exclusive theory to explain corporate law rights and duties. Both models fail to answer questions of importance to judges attempting to fashion a regime for takeover regulation that takes into account the legitimate public policy concerns implicated by transfers of corporate control and that is sustainably fair. Although the current state of play may leave the entity school adherents more satisfied than their counterparts in the property school, neither side is fully content. ${ }^{8}$

Rather than seek a common ground, however, each school appears content to advocate the pure form of its position. This apparent absence of desire to find a common ground suggests both that the status quo is in fact livable and that the debate is to some extent purely academic. We assume for the sake of argument, however, that both sides believe that the status quo could be improved in some incrementally valuable way.

Based on that assumption, we thought it productive to posit a system of takeover regulation that bridges some of the concerns of the property and entity models. We are by no means offering this proposal as our own personal preference. Rather, our intent is to use it as a catalyst to stimulate more productive debate about the proper structure for governing the corporation. We also, quite intentionally, borrow liberally from a provocative proposal advanced by Martin Lipton and Steven Rosenblum in the pages of this journal a decade ago. 30).

See, for example, Rowe, The Future of the "Friendly Deal" in Delaware (cited in note

87 Lipton and Rosenblum, $58 \mathrm{U}$ Chi L Rev 187 (cited in note 83). See also Melvin Eisenberg, The Structure of the Corporation 117-21 (Little, Brown 1976) (recommending that candidates nominated by more than 5 percent of the shares be included in the company's proxy materials). In their article, Lipton and Rosenblum, $58 \mathrm{U}$ Chi L Rev at 224-25, called for a system of quinquennial corporate elections. Under their concept, slates of directors would be expected to develop a long-term business plan and report on their attainment of that program at the next election. Id at 233-34. The quinquennial elections would provide challengers with access to corporate resources on an equal basis with the management slate. Id at 231 . Between elections, the directors' decisions about takeovers would be virtually conclusive. Id at $241-42$. Their idea was to focus directors on long-term planning to facilitate wealth creation. Id at 253 . Their article is detailed and provocative and we do not purport to do justice to it here. Suffice it to say we believe that it provides for too few elections to make its adoption attractive to those who embrace the property model. Moreover, its detailed structure limits the likelihood of its adoption. 
Our proposal is designed as a thought experiment, to test whether it is possible to locate a principled way to lessen the tension between the two models by (1) offering to the shareholder primacy advocates a corporate election system that has more integrity and competitiveness, (2) in exchange for according entity adherents a regime under which boards of directors would have clearer leeway to turn down takeover offers during the longer interval between elections.

The basic concept of our thought experiment is simple. Corporate boards would be elected every three years rather than annually. There is no mathematical precision to this, simply the intuition that corporate directors should have a tenure long enough to enable them to think and plan for the long term. ${ }^{8 s}$ In exchange for this greater insulation from the yearly electoral process, we would propose that the triennial elections be made genuinely fair by opening up the company's proxy machinery to all nominees having the support of a significant block of stock (we suggest from 5 percent to 8 percent). Any slate of nominees that satisfies this requirement would receive proxy expense advancement and proxy solicitation help on the same basis as the management slate of the corporation. In this way, the triennial election contest would afford stockholders a meaningful opportunity to participate in the election of the board. To institutional investors who claim to be long-term holders, this option should be attractive and be subject to regular use. To ensure that it works, federal regulators would have to cooperate by not restraining reasonable investor collaboration needed to meet the 5 percent (or 8 percent) threshold. Moreover, the expense advancement would have to include the costs of any federal securities filings that are needed to enable stockholders to advocate for their nominees.

88 Advocates of the property model might find the elimination of the annual election too big a price to pay for a reformed election process. This is a legitimate perspective because the property school might rightly say that shareholders should have to pay no price for a more competitive and fairer election system. But implementing such an election system annually might, on balance, be too expensive and inefficient to be in stockholders' best interests. Therefore, other forms of compromise are possible. For example, the annual election system could be retained, with the more open process we articulate only operating triennially. Likewise, elections under the open process could be held every two years. Like the ones raised later, see note 90 , these issues would merit serious thought if any implementation initiatives was undertaken. See generally Lucien Arye Bebchuk and Marcel Kahan, Framework for Analyzing Legal Policy towards Proxy Contests, 78 Cal L Rev 1073 (1990) (discussing a wide array of relevant concerns, including the costs and benefits of electoral reforms giving dissidents greater access to corporate resources to conduct proxy fights). One countervailing benefit from this reform for the property school is that the reform most logically entails the elimination or reform of the classified board system. Under a strong form of this reform, the classified board would be eliminated altogether. Under a weaker form, the open election process would function annually in those corporations whose boards continued to be classified.

89 By noting these issues only summarily, we do not mean to slight their importance. Insti- 
Our thought experiment could be implemented in a strong form version in which all corporations formed before and/or after the date of a statutory amendment would have this election structure (unless the charter opted out). Or it could be adopted in a weaker form, in which the statutory default would be reset so that the statute would expressly permit corporate charters to provide that election would be held only once every three years."

Underlying this thought experiment is a basic quid pro quo. The property model proponents essentially must acknowledge the republican democracy model of corporate governance. ${ }^{91}$ They would also forgo the annual corporate election process, as well as the ability to remove directors without cause by the written consent mechanism in exchange for a genuinely fair triennial election system. The entity model proponents would give up the currently management-biased election system, in exchange for directors having longer terms during which they would not be subject to removal.

Between elections, the directors would be subject to the Unocal standard of judicial review of whatever antitakeover defensive measures they adopt, and would be subject to the Revlon standard of review of any transaction involving a sale of control. Because of the

tutional investors will rightly be concerned with SEC compliance issues and any effective implementation of a reform of this kind must deal sensitively and responsively with them. Other commentators believe, however, that these issues do not present an insurmountable barrier to effective electoral action by institutional investors. See Ronald J. Gilson and Reinier Kraakman, Reinventing the Outside Director: An Agenda for Institutional Investors, 43 Stan L Rev 863, 894904 (1991).

90 One of the problems the property school has with Delaware law is the absence of any opportunity for stockholders to initiate a certificate amendment. See Bebchuk and Ferrell, 87 Va L Rev at 124-25 (cited in note 50). To address this concern, any implementing statute might accord stockholders a window to initiate a vote to opt into the new electoral system.

We also recognize that other issues would need to be addressed if a proposal of this sort were to be adopted. For example, an issue that might arise under the strongest form in which this idea could be adopted is that smaller corporations may find the triennial election cycle too lengthy. This problem may be minimized, as we suggest, by permitting corporations to have shorter election cycles by certificate. Likewise, to the extent that the annual meeting tradition is believed to have a value that is independent of the director election process-for example, in providing a forum for the expression of shareholder voice-there is no reason that tradition cannot be continued divorced from its tie to an annual election of directors. These and other issues would obviously have to be addressed if a proposal of this type were to be given serious consideration as a statutory reform.

91 By invigorating the corporate election system, the system we advocate should make corporate directors more accountable to the stockholders. By more firmly embracing the republican democracy approach, our system also makes clear that the acceptance of a takeover, like the implementation of a merger, would in most circumstances require bilateral action by both the board and stockholders. Professors Kahan and Rock argue that bilateralism of this kind may be the best way to generate wealth, because it encourages cooperation and an alignment of interests between management and the stockholders. See Marcel Kahan and Edward B. Rock, How 1 Learned to Stop Worrying and Love the Pill: Adaptive Responses to Takeover Law, $69 \mathrm{U}$ Chi L Rev 871 (2002). 
elimination of annual elections, the "proxy out" would no longer be an answer to the "just say no" issue. Instead, the propriety of a "just say no" defense would be assumed so long as that defense is justified as a reasonable exercise of judgment by disinterested, informed directors.

This new system addresses many of the problems associated with each model of the corporation. By giving directors longer terms, it addresses the entity model's concern that corporations have a long-term value that should not be subject to capture by the whims of a current array of short-term stockholders. The new system also corrects a flaw in the entity conception of the corporation by creating a fairer election system that operates functionally at all times, and not only when a takeover offer is on the table. Finally, the new system affords stockholders who are genuinely long-term, active investors an opportunity to ensure that corporate boards will consist of persons stockholders believe will be diligent creators and maintainers of shareholder value. In this sense, the election process could become a feasible method to replace poorly performing management, even when no hostile bid is pending."

As noted earlier, the new system also requires both sides to give a little. The stockholder primacy advocates must accept that the market for corporate control is one in which the primary decisionmakers would be corporate directors, and not the stockholders. The ability of a tender offeror to present an offer will depend most importantly on the offeror's ability first to convince a board of directors that the offer should be accepted. There will be no ability to "end-run" the directors except through the triennial election process or by persuading a court

92 Active institutional investors have developed a variety of methods to encourage better management, including publicity designed to "shame" bad managers and the boards who tolerate their continued employment. Under this new approach, a more direct way to replace management would be available.

It is, of course, true that many institutional investors will sell rather than undertake the extreme measure of commencing a hostile proxy fight. These institutional investors often value their access to management, and would fear that threatening such a fight might compromise that method of communication. This concern, however, perhaps slights the important way in which this type of reform might give institutional shareholders more say up front about, for example, who should comprise the independent directors proposed as part of the management slate. That is, the potential that institutional investors could run a proxy fight if they so chose would, it can be argued, give management a significant incentive to speak to these investors in advance about board composition issues. This would result in management slates that are more to the liking of stockholders in the first place, thereby avoiding the need for proxy fights.

Indeed, in the wake of the Enron scandal, shareholder activists appear to be examining closely whether to be more involved in proposing their own candidates for independent director seats. See Leah N. Spiro, More Scorn, Fewer Giggles at This Year's Meetings, NY Times B4 (Feb 17, 2002). Moreover, just last year, dissident stockholders elected a rival slate to fill one third of a classified board in a very expensive fight at ICN Pharmaceuticals, and are proposing another slate this year. Id. The cost savings of a more open election process would make more of these proxy fights economically feasible. 
that the board was not exercising a reasonable, good-faith business judgment in resisting an unsolicited takeover bid.

For their part, the entity advocates will have to abide a system in which the stockholders, and not corporate management, also have a fair and equal opportunity to determine who will be the directors empowered to make those key critical decisions. That is, the "republican democrats" will have to agree to reform the election process upon which they base their claims for the inviolability and legitimacy of the board's power to reject takeover offers. Arguably, this new system represents a pragmatic balance of various interests. By ensuring open elections every three years, the new system exposes corporations periodically to the rigors of the market for corporate control, thus giving boards incentives to remain attentive to the need to create shareholder value. The election reform also gives a leg up to investors who keep their capital in specific corporations on a long-term basis, by giving those investors a fair and efficient way to participate in shaping the composition of the board.

By giving boards freedom from distraction to manage the corporation without an annual election contest (and without being subject to removal at any time by shareholder written consent), the system gives the directors breathing room to think about corporate performance on more than a quarter-to-quarter basis. This system also creates useful space for boards to give some weight (if they are so inclined) to other constituencies. Finally, the new system eliminates some of the happenstance that factors so prominently into the resolution of current takeover fights. Neither the property nor the entity model is comfortable with the extent to which tender offer disputes turn on whether a corporation's charter contains a provision eliminating stockholder action by written consent or a classified board structure. No longer would a company's defensive profile be a critical factor in its vulnerability to an acquisition. Instead, the question would become whether the directors, whom the stockholders have had a meaningful opportunity to select, support or oppose the transaction.

Is the basic tradeoff one that proponents of the two models can live with? Let the debate begin. 


\title{
SYMPOSIUM: \\ MANAGEMENT AND CoNTROL OF THE MODERN BUSINESS CORPORATION
}

\author{
CORPORATE SPEECH AND CITIZENSHIP
}

Corporate Political Speech, Political Extortion, and the Competition for Corporate Charters Robert H. Sitkoff 1103

Commentary on Sitkoff Omri Yadlin 1167

Discussion moderated by Keith Scharfman

Corporate Charitable Victory Brudney

Giving \& Allen Ferrell 1191

Commentary on Brudney and Ferrell .Richard W. Painter 1219

Discussion moderated by Julie Roin 


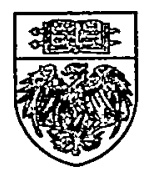

